CZASOPISMO INŻYNIERII LĄDOWEJ, ŚRODOWISKA I ARCHITEKTURY JOURNAL OF CIVIL ENGINEERING, ENVIRONMENT AND ARCHITECTURE

JCEEA, t. XXXIII, z. 63 (4/16), październik-grudzień 2016, s. 589-596

\author{
Agnieszka SZYMANOWSKA-GWIŻD $\dot{Z}^{1}$ \\ Bożena ORLIK-KOŻDOŃ ${ }^{2}$ \\ Paweł KRAUSE ${ }^{3}$ \\ Tomasz STEIDL ${ }^{4}$
}

\title{
ZMIANY ZAWILGOCENIA PRZEGRÓD BUDYNKÓW HISTORYCZNYCH PRZY ZADANYCH WARUNKACH KLIMATU ZEWNĘTRZNEGO
}

\begin{abstract}
$\mathrm{W}$ artykule przedstawiono analizę stanu wilgotnościowego przegrody z muru pruskiego, ocieplonego od strony pomieszczeń, wykonaną na podstawie rocznych symulacji z zastosowaniem programu WUFI.

W badaniach uwzględniono różne usytuowania przegrody względem stron świata, oraz zadano lokalne warunki klimatu zewnętrznego. W ocenie występujących zjawisk związanych z migracją wilgoci, zwrócono uwagę na nietypową budowę przegrody i wynikające $\mathrm{z}$ niej konsekwencje. Wskazano miejsca o intensywnej reakcji na czynniki higrotermiczne.

W analizowanej przegrodzie nie dochodzi do niepokojącej, utrzymującej się kumulacji wilgoci $\mathrm{w}$ warstwie ocieplenia ani na wewnętrznej powierzchni przegrody. $\mathrm{Z}$ przedstawionych analiz wynika, że w przypadku cienkiej ściany z muru pruskiego, izolowanego od wewnątrz pomieszczeń materiałem zapewniającym odpowiednią dyfuzyjność warstw, zagrożeniem dla historycznego układu przegrody wydaje się być wpływ zmian higrotermicznych na drewno i miejsca połączeń słupków $\mathrm{z}$ materiałem ceramicznym.
\end{abstract}

Słowa kluczowe: mur pruski, izolacja wewnętrzna, zawartość wilgoci, procesy higrotermiczne, obiekty historyczne

\footnotetext{
1 Autor do korespondencji / corresponding author: Agnieszka Szymanowska-Gwiżdż, Politechnika Śląska, Katedra Budownictwa Ogólnego i Fizyki Budowli, ul. Akademicka 5, 44-100 Gliwice, tel. 32237 2303; Agnieszka.Szymanowska-Gwiżdż@ polsl.pl

${ }^{2}$ Bożena Orlik-Kożdoń; Politechnika Śląska, Katedra Budownictwa Ogólnego i Fizyki Budowli, ul.Akademicka 5, 44-100 Gliwice, tel. 32237 2303; Bozena.Orlik-Kozdon@ polsl.pl

${ }^{3}$ Paweł Krause; Politechnika Śląska, Katedra Budownictwa Ogólnego i Fizyki Budowli, ul. Akademicka 5, 44-100 Gliwice, tel. 32237 2303; Pawel.Krause@polsl.pl

4 Tomasz Steidl; Politechnika Śląska, Katedra Budownictwa Ogólnego i Fizyki Budowli, ul. Akademicka 5, 44-100 Gliwice, tel. 32237 2303; Tomasz.Steidl@ polsl.pl
} 


\section{Wprowadzenie}

Zgodnie z obowiązującymi współcześnie przepisami przy projektowaniu nowych budynków należy uwzględniać liczne wymagania, w tym dotyczące izolacyjności termicznej oraz zabezpieczenia ich przed możliwością trwałego zawilgocenia. Projektowanie modyfikacji budynków istniejących, o charakterze zabytkowym, w tym poprawy ich właściwości termicznych, musi dodatkowo uwzględniać postulat zachowania wartości historycznych i kulturowych. W każdym z przypadków zastosowane rozwiązania techniczno - materiałowe nie mogą wpływać negatywnie na trwałość obiektu i jego bezpieczne użytkowanie.

Pokaźną część istniejących zasobów budowlanych Górnego Śląska stanowią obiekty z XIX i początków XX w, które podlegają zabiegom remontowym, w tym także termomodernizacyjnym. Z uwagi na wystrój elewacji lub konieczność zachowania jej niezmienionej formy, dominującą obecnie metodą wykonywania izolacji cieplnych $\mathrm{w}$ takich obiektach, jest jej mocowanie od strony wewnętrznej pomieszczeń. Takie rozwiązania, z zastosowaniem odpowiednich materiałów, coraz częściej stosuje się także w budynkach o konstrukcji szkieletowej, drewnianej, z wypełnieniem cegłą ceramiczną, w tzw. murze pruskim.

$\mathrm{Z}$ uwagi na swoją budowę (połączenie konstrukcji murowej z elementami drewnianymi) stanowią one przypadek szczególny, dla którego niezwykle ważne jest zastosowanie prawidłowo dobranych rozwiązań tak, aby nie powodować kumulacji wilgoci w przegrodzie. Może do niej dochodzić zarówno na skutek migracji pary wodnej od środka, jak również od zewnątrz, np. w związku z występowaniem opadów atmosferycznych. Charakterystyczną cechą przegrody z muru pruskiego jest występowanie szczelin pomiędzy szkieletem a przylegającymi elementami, umożliwiające wnikanie wody opadowej w głąb muru. Mogą one wynikać miedzy innymi z naturalnych procesów degradacji drewna. Zjawisko takie opisano $\mathrm{w}$ [1], zwracając uwagę na procesy starzeniowe i powolne ubytki przekrojów poprzecznych elementów drewnianych.

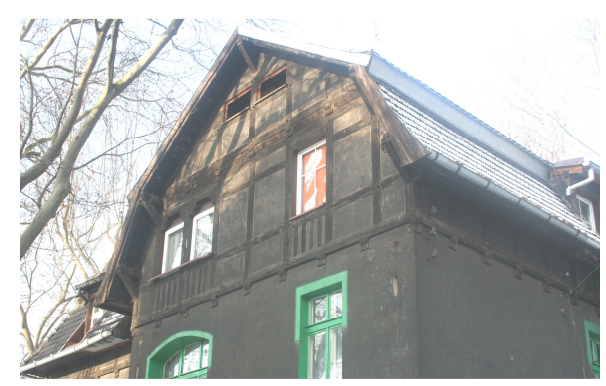

Rys. 1. Przykładowa zabudowa z murem pruskim na Górnym Śląsku

Fig. 1. Example of brick nogged timber wall building on Upper Silesia

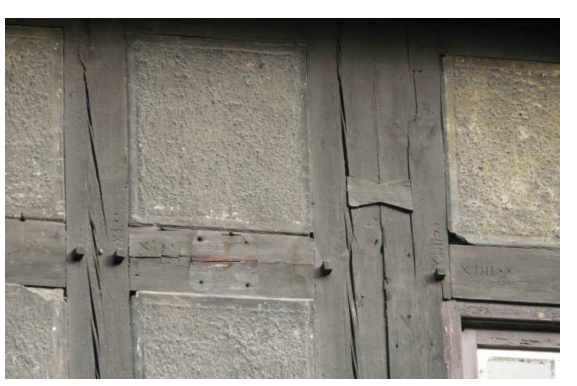

Rys. 2. Detal ściany z muru pruskiego

Fig. 2. Detail-brick nogged timber wall 
Odpowiednio dobrane ocieplenie nie powinno utrudniać migracji wilgoci z przegrody do wnętrza pomieszczeń (co ma miejsce w pierwotnej, historycznej budowie przegród, ze względu na małą grubość muru i brak powłok izolacyjnych). Wymagania dla ociepleń od wewnątrz ścian z muru pruskiego opisywano w literaturze, m.in. [2,3]. Zgodnie z [6] warstwa ocieplająca, wraz z wewnętrznym tynkiem lub okładziną i ewentualną paroizolacją powinna posiadać wartość Sd maksymalnie $2 \mathrm{~m}$. Rozwiązanie powinno umożliwiać również migrację do wnętrza, wilgoci gromadzącej się $\mathrm{w}$ przegrodzie $\mathrm{W}$ artykule przedstawione zostały wyniki symulacji obliczeniowych zmian zawartości wilgoci i temperatury $\mathrm{w}$ warstwach przegrody z muru pruskiego. Autorom zależało na pokazaniu tendencji zmian, w zależności od usytuowania ścian względem stron świata. Analizy transportu wilgoci w przegrodzie wykonano przy wykorzystaniu programu WUFI.

\section{Opis badań}

\subsection{Przyjęte założenia}

Badania symulacyjne wykonano dla przegrody z muru pruskiego - przegroda o grubości wypełnienia ceglanego $12 \mathrm{~cm}$, z pokryciem tynkiem wapiennocementowym o grubości $2 \mathrm{~cm}$, słupy drewniane $14 / 14 \mathrm{~cm}$, wnętrze pokryte tynkiem wapiennym, grubości $2 \mathrm{~cm}$, ocieplona od wewnątrz bloczkami z betonu komórkowego, gr. $6 \mathrm{~cm}$.

Parametry materiałowe (tab. 1) przyjęto $\mathrm{z}$ danych bazy programu WUFI: dla cegły historycznej i drewna twardego. Odległość pomiędzy slupami określono na podstawie pomiarów inwentaryzacyjnych budynku usytuowanego w osiedlu Zandaka w Zabrzu - jako $100 \mathrm{~cm}$.

Tab. 1. Dane materiałowe [6]

Tab. 1. Material data [6]

\begin{tabular}{|c|l|c|}
\hline Lp. & \multicolumn{1}{|c|}{ Materiał } & $\lambda[\mathbf{W} / \mathbf{m K}]$ \\
\hline 1 & Zaprawa wapienna drobna $1785 \mathrm{~kg} / \mathrm{m}^{3}$ & 0,7 \\
\hline 2 & Cegła pełna historyczna1850 kg/m $\mathrm{m}^{3}$ & 0,60 \\
\hline 3 & Drewno twarde $650 \mathrm{~kg} / \mathrm{m}^{3}$ & 0,13 \\
\hline 4 & Zaprawa cementowo-wapienna grubsza $1910 \mathrm{~kg} / \mathrm{m}^{3}$ & 0,80 \\
\hline 5 & Bloczki z betonu komórkowego $115 \mathrm{~kg} / \mathrm{m}^{3}, \mu=3$ & 0,042 \\
\hline
\end{tabular}

Początkową zawartość wilgoci materiałów przyjęto jak dla stanu równowagi. Parametry klimatu wewnętrznego (tab. 2) określono jak dla pomieszczeń mieszkalnych. Założono warunki sinusoidalne (temperatura $\mathrm{t}_{\mathrm{i}}=20+/-2^{\circ} \mathrm{C}$, wilgotność $\varphi \mathrm{i}=50+/-10 \%)$. Określono warunki klimatu zewnętrznego dla obszaru Górnego Śląska (ze stacji meteorologicznej w Katowicach), w postaci tempera- 
tur zewnętrznych, wilgotności powietrza, opadów atmosferycznych i nasłonecznienia. Dla ściany zachodniej uwzględniono dodatkowo wpływ zacinającego deszczu (zgodnie z najczęstszym kierunkiem wiatru dla rejonu Śląska). Przyjęto roczny okres symulacji higrotermicznych.

W symulacjach uwzględniono dwa usytuowania przegrody względem stron świata. Pod uwagę wzięto ścianę północną (z uwagi na małe nasłonecznienie oraz zachodnią (z uwagi na główny kierunek wiatru).

Tab. 2. Przyjęte warunki klimatu zewnętrznego

Tab. 2. Adopted external climate conditions

\begin{tabular}{|c|l|c|}
\hline Nr & \multicolumn{2}{|c|}{ Klimat zewnętrzny } \\
\hline 1 & Średnia temperatura powietrza zewnętrznego $\left[{ }^{\circ} \mathrm{C}\right]$ & 8.1 \\
\hline 2 & Maksymalna temperatura powietrza zewnętrznego $\left[{ }^{\circ} \mathrm{C}\right]$ & 30.4 \\
\hline 3 & Minimalna temperatura powietrza zewnętrznego $\left[{ }^{\circ} \mathrm{C}\right]$ & -16.0 \\
\hline 4 & Średnia wilgotność względna powietrza [\%] & 80 \\
\hline 5 & Maksymalna wilgotność względna powietrza [\%] & 100 \\
\hline 6 & Minimalna wilgotność względna powietrza [\%] & 29 \\
\hline 7 & Średnia prędkość wiatru [m/s] & 4.36 \\
\hline 8 & Suma opadów [mm/a] & 493 \\
\hline
\end{tabular}

\subsection{Wyniki obliczeń $\mathrm{i}$ ich analiza}

Wyniki obliczeń wykonanych w programie WUFI przedstawiono w postaci graficznej. Określone zostały zmiany rozkładu temperatury wilgotności względnej [\%] i zawartości wilgoci $[\mathrm{kg} / \mathrm{m} 3$ ] (rys. $3 \div 12$ ) w analizowanej przegrodzie budowlanej, w jej poszczególnych warstwach, po ociepleniu przegród od strony pomieszczeń.

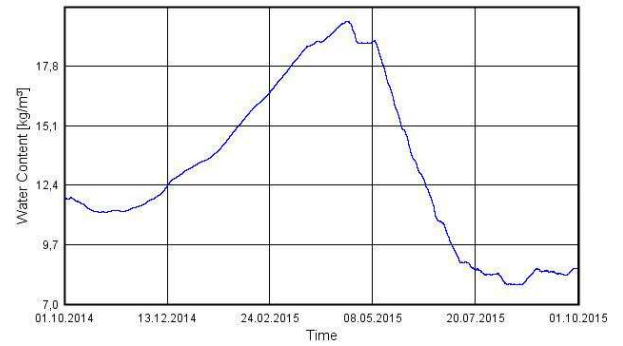

-Water Content

Rys. 3. Zawartość wilgoci w murze ceglanym, ściana północna

Fig. 3. Brick wall moisture amount, north wall

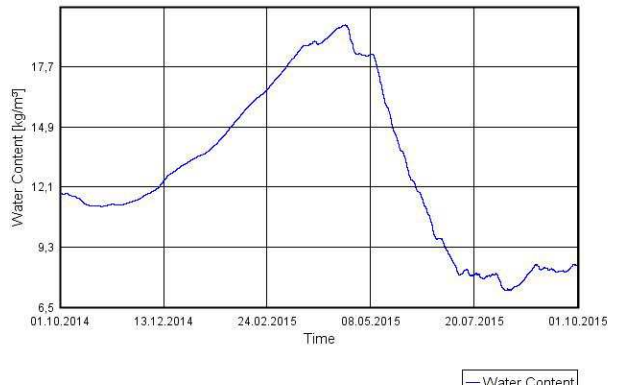

Rys. 4. Zawartość wilgoci w murze ceglanym, ściana zachodnia

Fig. 4. Brick wall moisture amount, west wall 


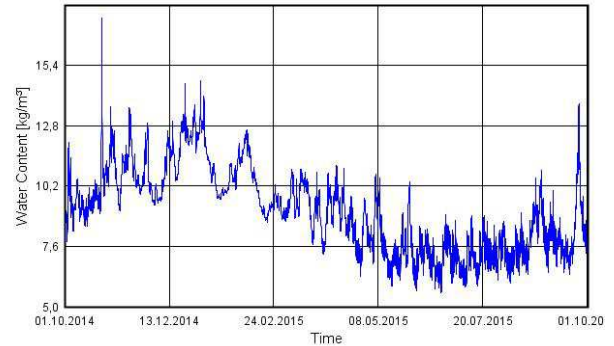

-Water Content

Rys. 5. Zawartość wilgoci w tynku zewnętrznym, ściana północna

Fig. 5. External plaster moisture amount, north wall

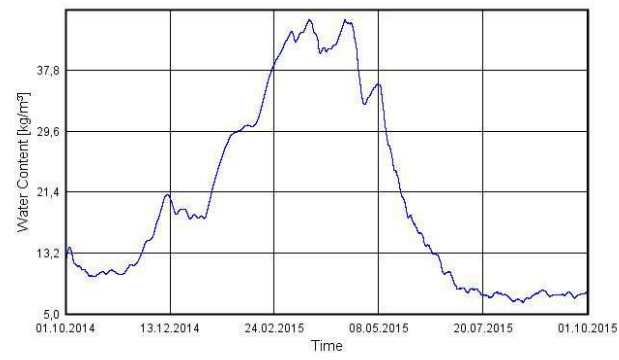

-Water Content

Rys. 7. Zawartość wilgoci w tynku wewnętrznym, ściana północna

Fig. 7. Internal plaster moisture amount, north wall

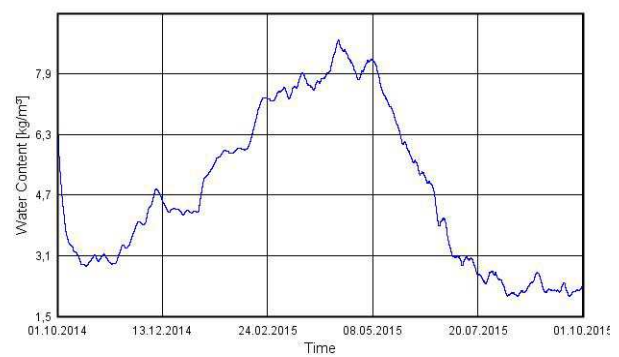

-Water Content

Rys. 9. Zawartość wilgoci w bloczku betonowym, ściana północna

Fig. 9. Concrete block moisture amount, north wall

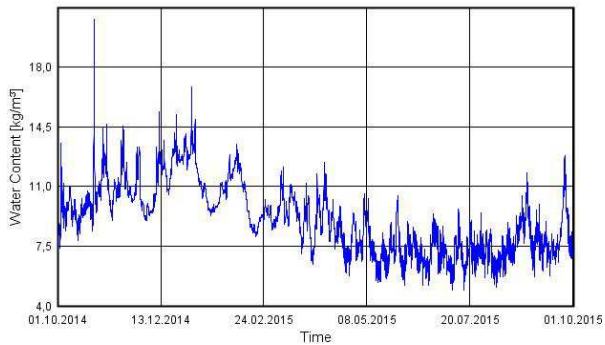

-Water Content

Rys. 6. Zawartość wilgoci w tynku zewnętrznym, ściana zachodnia

Fig. 6. External plater moisture amount, west wall

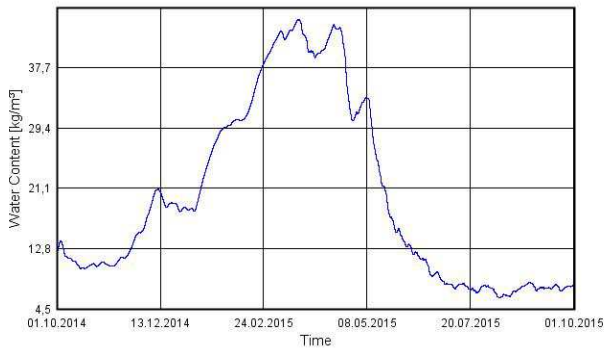

-Water Content

Rys. 8. Zawartość wilgoci w tynku wewnętrznym, ściana zachodnia

Fig. 8. Internal plater moisture amount, west wall

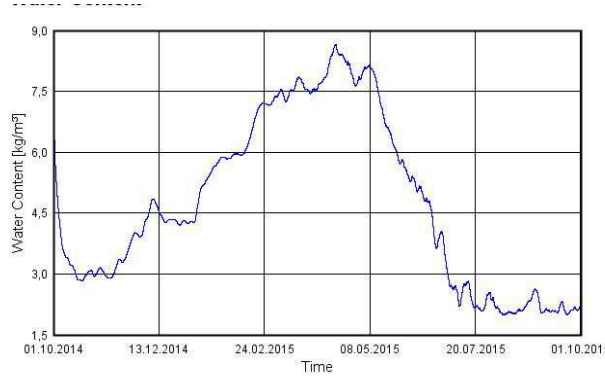

-Water Content

Rys. 10. Zawartość wilgoci w bloczku betonowym, ściana zachodnia

Fig. 10. Concrete block moisture amount, west wall 
Dla rocznego okresu symulacji zaobserwować można tendencje zmian zawartości zawilgocenia warstw w poszczególnych miesiącach z przewidywanym kierunkiem migracji. W okresie jesiennym wpływ zewnętrznego klimatu uwidacznia się najmocniej w tynku zewnętrznym, w postaci przedstawionych na rys. 5 i 6 , silnych i gwałtownych wahnięć wykresów. Dopiero od lutego zmniejsza się ich amplituda, ostatecznie ściana zachodnia, poddana silniej wpływom opadów atmosferycznych, wykazuje większą sprawność odsychania od ściany północnej. Jej usytuowanie sprawia, że poddawana zostaje nasłonecznieniu oraz większym wpływom wiatrów (główny kierunek wiatrów w tym rejonie). Część zawilgocenia migruje do środka przegrody. Poziom zawilgocenia muru wzrasta stopniowo, w zbliżonej postaci dla ściany północnej i zachodniej, aż do kwietnia, kiedy to następuje stopniowe ich odsychanie. Marzec i kwiecień to miesiące, w których zaobserwować można maksymalną zawartość wody w tynku wewnętrznym, podobną $\mathrm{w}$ obu przypadkach usytuowania ściany. Jednak w końcowej fazie okresu obliczeniowego poziom zawilgocenia w ścianie północnej jest nieznacznie wyższy niż w ścianie zachodniej. W warstwie ocieplenia wewnętrznego okres maksymalnego zawilgocenia przypada na miesiące od marca do maja, jednak jest on znacznie niższy niż w warstwie muru i tynku wewnętrznego. Mur ceglany zaczyna wyraźnie odsychać w maju, szczyt zawilgocenia izolacji wewnętrznej przypada na kwiecień, co może oznaczać, że na jego poziom w tym okresie ma wpływ migracja wilgoci z pomieszczeń. Ostateczne wartości określające zawartość wody w warstwie izolacji, po rocznym okresie symulacji dla obydwu usytuowań ścian, nie odbiegają znacznie od siebie. Nie dochodzi do niepokojącej kumulacji wilgoci wewnątrz przegrody ani na jej wewnętrznej powierzchni.

$\mathrm{Z}$ przedstawionych analiz wynika, że w przypadku cienkiej ściany z muru pruskiego, izolowanego od wewnątrz pomieszczeń materiałem izolacyjnym zapewniającym odpowiednią dyfuzyjność przegrody, większym zagrożeniem dla historycznego układu przegrody wydaje się być wpływ zmian higrotermicznych na drewno i miejsca połączeń słupków z materiałem ceramicznym. Choć poziom zawilgocenia drewna w okresie wczesnowiosennym (marzec-kwiecień) okresowo zwiększa się do poziomu ok. $107 \mathrm{~kg} / \mathrm{m}^{3}$ (16,5\%, określanych w procentach wagowych w stosunku do suchej masy materiału), to jednak w kolejnych miesiącach wysycha do bezpiecznego poziomu ok. $83 \mathrm{~kg} / \mathrm{m}^{3}$ (ok. 13\%). Niepokojący jednak wydaje się być wpływ odizolowania warstw zewnętrznych ściany od ciepłego wnętrza z powodu zastosowania wewnętrznej izolacji termicznej. Z rys. 13 i 14 wynika, że temperatura na powierzchni drewna, w styku z wewnętrznymi warstwami spada w okresie zimowym do kilku stopni poniżej zera. Największy wpływ warunków klimatu zewnętrznego zaobserwować można w miejscu styku drewna ze ścianą ceglaną, w postaci występowania tam temperatur ujemnych ale także i wysokich dodatnich temperatur w okresie letnim. Rys. 13 obrazuje zmiany temperatur $w$ zaznaczonych miejscach słupów drewnianych $w$ jego wnętrzu i $\mathrm{w}$ miejscu połączenia $\mathrm{z}$ fragmentami ceglanymi. W pracy [4] autorzy 
zwracali uwagę na występowanie znacznych różnic w gęstościach strumienia ciepła w miejscu połączeń tych materiałów i występowanie tam szczelin. Przeprowadzone symulacje stwarzają podstawę do przypuszczenia iż miejsca te należy brać pod szczególną uwagę, z punktu widzenia trwałościowego, projektując ocieplenie przegród po stronie pomieszczeń.

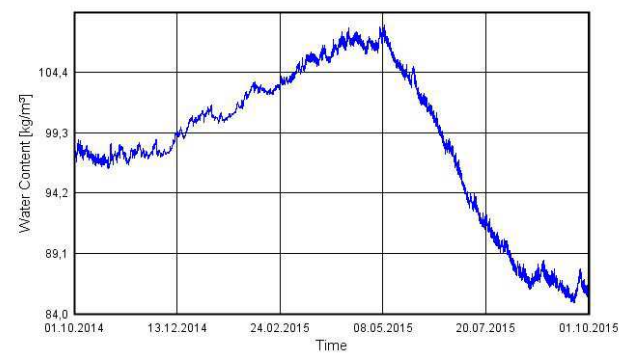

-Water Content

Rys. 11. Zawartość wilgoci w słupku drewnianym, ściana północna

Fig. 11. Timber column moisture amount, north wall

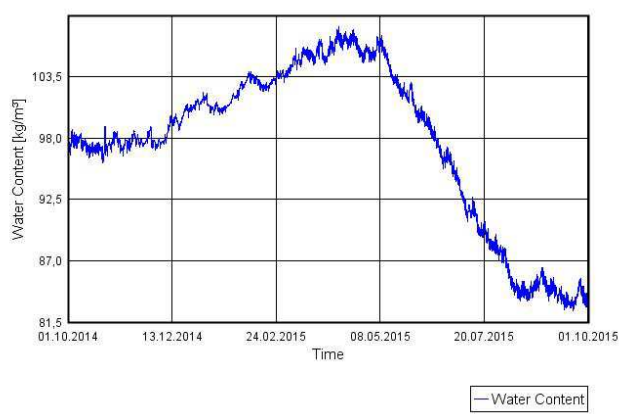

Rys. 12. Zawartość wody w słupku drewnianym, ściana zachodnia

Fig. 12. Timber column moisture amount, west wall

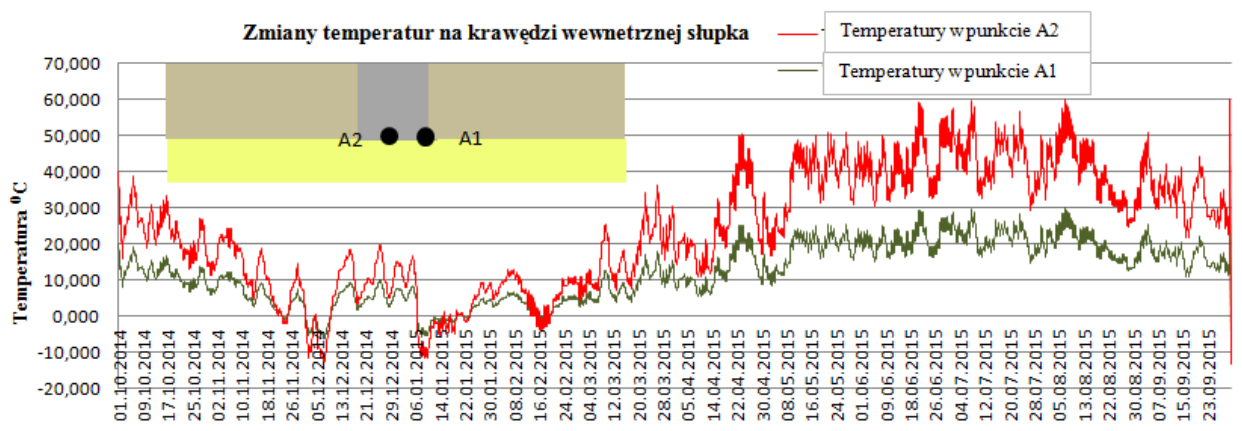

Rys. 13. Zmiany temperatur w zadanych punktach na krawędzi wewnętrznej słupka

Fig. 13. Column internal edge's temperature variations at the predetermined points

\section{Wnioski końcowe}

Projektowanie poprawy właściwości cieplnych budynków historycznych powinno być poprzedzone analizą $\mathrm{w}$ zakresie stanu istniejącego obiektu oraz szczegółową weryfikacją planowanych rozwiązań projektowych, w oparciu o dostępne narzędzia badawcze, zwłaszcza przy zastosowaniu izolacji termicznej od wewnątrz pomieszczeń. Analiza stanu istniejącego pozwala na ustalenie rozwiązań materiałowych oraz aktualnych właściwości termicznych i wilgotnościowych przegród. 
Przeprowadzone symulacje obrazują tendencje zmian cieplno wilgotnościowych $\mathrm{w}$ poszczególnych warstwach przegrody. W celu prognozowania procesów z zakresu przepływu ciepła i wilgoci oraz ich wpływu na trwałość historycznych, nietypowych dla środkowoeuropejskiego obszaru przegród z muru pruskiego niezbędnym wydaje się być określenie fizyko-mechanicznych danych materiałowych (jak porowatość, nasiąkliwość czy wytrzymałość). Wskazane jest także ustalenie rzeczywistych warunków klimatu wewnętrznego, zgodnego $\mathrm{z}$ aktualnym wykorzystaniem funkcjonalnym pomieszczeń, oraz przyjecie dłuższego okresu obliczeniowego. W szczególności obserwacją należy ująć miejsca połączeń drewna z materiałem ceramicznym.

\section{Literatura}

[1] Kozakiewicz P., Matejak M.: Klimat a drewno zabytkowe. Dawna i współczesna wiedza o drewnie, Warszawa, Wydawnictwo SGGW 2013.

[2] Radoń J., Kuncel H., Olesiak J.: Problemy cieplno-wilgotnościowe przy renowacji ścian budynków z muru pruskiego, Acta Scientarum Polonorum, Architektura, Kraków 2006, s. 45-53.

[3] Radoń J., Kuncel H.: Zalety stosowania paroizolacji wspierających proces wysychania. Warstwy dachy ściany, 4/2004, s. 98-103.

[4] Szymanowska-Gwiżdż A., Steidl T.: Impact of building walls of historic objects from half-timbered wall in their state of thermal protection, Civil and Environmental Engineering Reports, $2016 \mathrm{nr} 20$ (1), s. 171-178.

[5] WTA-Merkblatt 8-1-96-D. Bauphysikalische Anforderungen an Fachwerkfassaden.

[6] WUFI - baza materiałowa programu komputerowego.

\section{MOISTURE VARIATIONS OF HISTORICAL BUILDINGS DIVISION WALLS IN ADOPTED EXTERNAL CLIMATE CONDITIONS}

\section{S u m m a r y}

Academic article contains brick nogged timber division wall's moisture conditions analysis, insulated from compartment side, elaborated on annual simulations prepared in WUFI software. Studies includes different division wall's site locations and adopted external local climate conditions. It was recorded in existing condition examination, regarding to moisture migration, atypical division wall construction and its consequences. Intense reaction areas for hygrothermic factors were indicated. In analyzed division wall there is no anxious continuous moisture accumulation in insulation layer and internal surface. As a analysis results, in thin brick nogged timber wall case, insulated from internal compartment side by material allowing coefficient layers diffusivity, there is a risk for historical division wall layer configuration caused by hygrothermical variation impact for wood and column with ceramic connection areas.

Keywords: brick nogged timber wall, internal insulation, moisture conditions, hygrothermal processes, historical buildings, division walls

DOI: $10.7862 / \mathrm{rb} .2016 .303$

Przestano do redakcji: $30.06 .2016 r$.

Przyjęto do druku: 20.12.2016 r. 